\title{
LEGUMES ARE A STRATEGIC FACTOR IN REGULATING PROTEIN BALANCE AND SOIL FERTILITY
}

\section{Victor Mazur ${ }^{1}$ \\ Ihor Didur ${ }^{2}$}

DOI: https://doi.org/10.30525/978-9934-26-021-6-32

Abstract. The monograph is aimed at solving current problems that guarantee food security of the state as the potential of Ukraine and intensive development of various options of new technologies, which will be provided through the development and implementation of the latest bioorganic model of varietal technology of legumes, taking into account climatic changes. on the basis of organic farming. From these positions, the studies are systemic in nature and focused on the long term in the format of natural factors of symbiotic nitrogen fixation and active stabilization of humification processes by reducing the rate of dominant processes of mineralization of the organic part of soils. Implementation of environmentally friendly direction will involve the development of measures for efficient waste management, rational use of biological resources by increasing the area and volume of grown cereals, as well as improving cultivation technologies, use of new varieties and hybrids of crops and land reclamation, taking into account the concepts of rational nature aimed at optimizing land use, biologization of agriculture. The implementation of the proposed measures is aimed at increasing the level of realization of the yielding varietal potential of the main legumes, increasing the profitability of their production in combination with environmental and social effects, ensuring reduction of soil degradation processes in Ukraine.

\section{Introduction}

An urgent problem for Ukraine is the development of alternative farming systems in the direction of developing new organic technologies for growing

\footnotetext{
${ }^{1}$ Candidate of Agricultural Sciences, Professor, Rector of

Vinnytsia National Agrarian University, Ukraine

${ }^{2}$ Candidate of Agricultural Sciences, Associate Professor,

Vinnytsia National Agrarian University, Ukraine
} 
basic agricultural products. crops, in accordance with the directions of the European strategy for the development of biological systems of crop and livestock. Unlike other methods of agriculture, organic production is based on the use of resource-saving technologies, minimization of mechanical tillage and eliminates the use of synthetic substances.

The monograph has a complex multidisciplinary and systemic nature in the combination of adaptive farming systems and adaptive fertilizer systems given the current trends of climate change in the context of: 1) implementation of the national program "Grain of Ukraine», which provides for 80 million tons of grain annually; 2) creation of effective mechanisms to increase soil fertility based on the accumulation of atmospheric nitrogen and the accumulation of organic matter in order to enhance the processes of humification; 3 ) providing a qualitatively new feed base to improve the conversion of high-protein feed into livestock products.

The subject of research is a set of theoretical, methodological and practical factors for the development of bioorganic components of varietal technology for growing legumes on the factors of preserving soil conditions of soil fertility, taking into account changes in climatic factors and changes in the spectrum of crop production.

The monograph is a significant contribution to solving current issues of promising strategic direction of development of the agro-industrial complex of Ukraine. Scientific work is aimed at achieving a comprehensive effect in ensuring sustainable agro-industrial production while guaranteeing the necessary levels of food and bioenergy security of the state while preserving and reproducing soil fertility potential and improving living conditions and public health by increasing access to production and consumption of organic agricultural products.

The monograph presents a competitive bioorganic varietal technology for growing legumes, which provides for the development of regulations for the use of a set of alternative fertilizers for their cultivation in terms of short-term and long-term action and the basic superstructure of factor assessment of soil fertility, ecological conditions.

The scientific novelty of the obtained results is presented by an innovative method of assessing the bioadequate productivity of arable land to determine the possibility of adaptation of the enterprise to bioorganic technologies for growing legumes; developed effective regulations for 
the use of different types of biofertilizers for their vegetation and biosoil preparations by classical types in the system of agrotechnologies for growing this group of crops; developed a comprehensive strategy for the transition to bioorganically adapted varietal technologies for growing legumes, taking into account the resource supply of the enterprise and hydrothermal supply of the territory. Scientific researches of the team of authors are directed on the decision of actual problems of technological updating and development of an agro-industrial complex on the basis of development of bioorganic models of varietal technology of cultivation of legumes.

As part of joint research work of Vinnytsia National Agrarian University and the Institute of Bioenergy Crops and Sugar Beets of the National Academy of Agrarian Sciences of Ukraine, the authors of the monograph Victor Mazur, Ihor Didur and Hanna Pantsyreva are executors of applied research on the topic: «Development of methods for improving the technology of growing legumes using biofertilizers, bacterial preparations, foliar fertilizers and physiologically active substances» (Mazur V., Didur I., Ivanina V., Tkachuk O., Pantsyreva H., Vradiy O.), state registration number 0120U102034. According to the results of the applied research, which is carried out at the expense of the state budget, it is envisaged to scientifically substantiate the agro-ecological aspects of technological methods of growing legumes, which are covered in the submitted monograph. The data presented in the monograph are the result of joint research work between ESIC «Ukrainian scientific-educational consortium» and Vinnytsia National Agrarian University, confirmed by the implementation of economic contract «Development of a control system for C-carbon and N-nitrogen and their impact on the operation of biogas plants running on multicomponent raw materials» (state registration number 0118U100523).

The scientific and methodological value of the monograph lies in the presentation of the results of research conducted on the basis of the Research Farm «Agronomic» Vinnytsia National Agrarian University, the village of Agronomiche, Vinnytsia district, Vinnytsia region. Scientific substantiation of technological methods of growing legumes allows to modernize the system of training of future specialists in the field of agrotechnologies and to increase the production and practical orientation of such professional training.

The monograph is a significant contribution to solving the problems of increasing the level of realization of the yielding varietal potential of 
legumes, increasing the profitability of their production in combination with environmental and social effects. The peer-reviewed work is performed in line with a new direction of research focused on the integration of paradigms of scientific knowledge in the field of crop production and agriculture, as well as on the synthesis of different concepts of domestic and world practice. This, according to the authors of the study, allows us to approach the understanding of a complex, multifaceted and holistic assessment of technological methods of growing legumes.

\section{Analysis of recent research and publications}

Issues of optimization of the structure of sown areas of legumes and their role in regulating soil fertility and increasing the productivity of farm animals are given in studies Cherenkov A. (2016), Shevchenko M. (2016). Models of crop rotations with elements of biologization at saturation by their legumes are developed, and also offers concerning complex development of branch of grain production Petrychenko V. (2014), Chynchyk O. (2019), Kalenska S. (2015), Cherenkov A. (2016), Bakhmat O. (2018), Pantsyreva H. (2017). Studies of the effectiveness of biofertilizers and biostimulants have been actively conducted in Ukraine since the 1990s. These issues have been fruitfully discussed over the past five years in the studies of Beloved A. (2016), Vinyukova O. (2015), Volkogon V. (2015), Breginets O. (2015), Polishchuk I. (2015), Naidenova O. (2015), Kovalenko O. (2015), Dubovyka D. (2016), Sokol S. (2016), Koltunova V. (2018) and others. Implementation of bioorganic methods of cultivation have dedicated their works Petrychenko V. (2018), Mazur V. (2017), Patyka V. (2015), Babych O. (2017), Kolisnyk S. (2015); Shevnikov M. (2019), Kots S. (2016), Kaminsky V. (2017), Bakhmat O. (2018), Sherstoboeva O. (2016), Elsheikh E. (2016), Tagore G. (2016), Mishra A. (2016) and others. In the works of Dubovyk D. (2016) highlights the results of studying the impact of individual biological products of microbial nature on the formation of yield and quality of legumes. Similar studies on cereals and industrial crops are given in the works of Sokola S. (2016), Koltunova V. (2018) and others. Some aspects of biological fertilizer for soybeans were published in the studies of Grigorieva O. (2014), Hungry A. (2015). General recommendations for the use of biofertilizers and biostimulants by groups of crops are reflected in the work of Volkogon V. (2015). Among foreign scientists, the generalization of 
the results of studying the effectiveness of biofertilizers of various origins was carried out in the works of J.D.S. Panwar (2016), H. Panda (2017), on some crops - soybeans and corn - M.A. Laditi1, O.C. Nwoke, M. Jemo, R.C. Abaidoo, A.A. Ogunjobi (2015), D. Matthew (2017).

Unresolved issues of these studies, taking into account the positive effect found mainly during the application of biological fertilizer systems are the complexity of biofertilizers in seed treatment, soil application, application in several stages during the growing season using biofertilizers of different nature from symbionts, humates to complex biocomponents. foliar feeding format. An important aspect of research remained the study of the interaction of biopotential of legumes in the soil-plant system from the standpoint of the potential for accumulation of biological nitrogen, the impact on nutrient and microbiological regime of soils and its biota, the impact of legumes as precursors. According to the authors of the monograph, the expected scientific solutions, namely technological modernization of agriculture, the involvement of artificial means of regulating plant productivity, significant climate change, it is important to determine through innovative landmarks in land use, crop area, fertilizers and organic residues legislative consolidation of scientifically substantiated positions.

\section{Literature review}

In the period of development of European integration and globalization of the domestic economy, the production of legumes requires a flexible approach to international competition, ensuring solutions to food and environmental security. Legumes play an important role in the grain and fodder balance of agricultural formations in Ukraine. Of all crops, legumes contain the most protein. Their grain and green mass in terms of protein content exceeds cereals more than twice, in terms of amino acid composition their proteins are much better digested, give the cheapest protein, include in the biological cycle nitrogen air, which is not available for other crops. Today, vegetable protein is highly valued in the food and feed industry.

Strategically, Ukraine should take a course to reduce the export of raw materials and create conditions for the organization of in-depth processing, which will contribute to: meeting the needs of intensive animal husbandry with high-protein feed; creation of additional jobs; increase in tax revenues; ensuring food and environmental security of Ukraine. 
In Ukraine and the world there are problems with soil fertility, which results in a gradual reduction of soils with a high content of humus, as well as phosphorus and potassium. At the same time, the areas of soils with a low level of supply of these substances are increasing. According to rough estimates, since the beginning of Ukraine's independence, the total area of nutrient-depleted soils is hundreds of thousands of hectares. Against this background, the total area of legumes in Ukraine has more than halved, and in the global dimension by $25-32 \%$. Due to this, in the opinion of scientists, soils do not receive more than a third of the potentially possible symbiotically fixed nitrogen. For these reasons, the problem of oversaturation with industrial and grain crops, in particular wheat and corn, is acute. This creates the danger of intensive monocultural production, which in the end is a real threat to both Ukraine and the world in terms of food security.

The authors' developments are aimed at solving a defined range of problems by adapting existing technologies to the dominant global trends in fertilizers, the range of bioorganic drugs, trends in the intensive formation of the market for organic products.

Intensification of grain production, including fodder, should become one of the strategic directions of accelerated development of all agro-industrial production of Ukraine by 2030. For this purpose it is necessary to focus on creating high-yielding varieties with clarification of stable production zone introduction of science-intensive, innovative technologies for their cultivation, which will be based on the effective use of life factors (light, heat, moisture, nutrients), which will promote maximum synthesis of organic matter and protein. The oil and fat subcomplex of our state on the way to European integration needs to be modernized. In addition, in the context of climate change, it will be necessary to form a common agricultural policy for the production of high-protein crops with the EU. This is an urgent and important task, the solution of which will be a significant contribution to solving the problem of vegetable protein, the formation of its own protein resources, increasing soil fertility and strengthening the economy of Ukraine.

The working hypothesis of the research is based on an effective system of gradual effective replacement of classical agrochemicals with complex bioorganic chelate complexes capable of efficiently and point-by-point 
regulation of physiological processes of the plant organism. In the case of legumes, this will not only significantly reduce the agrochemical load on the soil cover, but also contribute to the gradual restoration of soil fertility by increasing the area under legumes and attracting biologically fixed nitrogen. As a result, it will contribute to the ecological and economic stabilization of agricultural areas and will form sustainable adaptive agricultural landscapes with projected levels of yield and production volumes.

The unstable situation in general in the domestic economy and its agricultural sector leads to the production of insufficient amounts of mineral fertilizers. Ukraine's dependence on their imports is growing, and after the recent devaluation of the hryvnia for domestic farmers, this product is becoming more expensive. According to the results of 2019, we are among the twenty countries with the largest volumes of fertilizer imports. At the same time, the issue of preserving and restoring soil fertility is acute, because the maximum efficiency of agricultural production can be ensured only through the rational use of the environment, scientifically sound application of fertilizers and the use of crop by-products. As a result of agricultural production, the structure was disrupted and the typical properties of Ukrainian chernozems changed.

In recent years, low levels of application of organic and mineral fertilizers for crops have been recorded in Ukraine. Thus, in 2019, $0.5 \mathrm{t} / \mathrm{ha}$ of organic fertilizers were applied, this figure remains virtually unchanged. And mineral fertilizers last year were applied in the amount of $96 \mathrm{~kg} / \mathrm{ha}$, their use tends to gradually increase.

At the same time, it is noted that the issue of soil quality and fertility has become very acute today, because these resources are not limitless. Intensive farming technologies, which have been widely used by farmers in recent decades, have led to a significant reduction in soil fertility, deterioration of their condition and basic properties. Therefore, the moment has come when it is necessary to change the principles of management. One of the main tasks of organic farming is to improve the condition of soils. It is noted that the planning of crop rotations for 5-7 years ahead with the mandatory inclusion of $30 \%$ of legumes. Planning crop rotations for such a long period can be a difficult task, because there are certain market needs that farmers want to track and take into account. However, it is necessary to learn to work with long-term planning to get good yields of legumes, and the need 
for adapted, modern technologies for growing crops such as chickpeas, lentils, rank, lupines is extremely acute, especially given current trends in fertilizers and alternative minimized tillage systems.

It should not be forgotten that the intensive chemicalization of the crop sector of agriculture in Ukraine is manifested primarily in the use of high rates of mineral fertilizers and repeated use of pesticides. This contributes to a significant increase in the yield of major crops. But at the same time, mineral fertilizers, especially nitrogen, cause mineralization of humus and acidification of the soil solution. Therefore, to further maintain existing crop levels, it is necessary to increase the rates of mineral fertilizers. In order to preserve and increase soil fertility, as well as increase their agroecological resistance to adverse anthropogenic factors, it is necessary to accumulate organic matter in the soil. Due to the sharp decline in livestock in Ukrainian farms, it is almost impossible to solve this problem by applying manure. Therefore, it is necessary to find ways to restore and maintain the optimal level of soil fertility through alternative ways of accumulating organic matter in the soil. One of the main resources and a promising direction in solving this problem may be the cultivation of legumes.

Legumes in crop rotation are one of the factors that can be used to stabilize the processes occurring in the soil-plant-animal-human system. The large phytomeliorative role of legumes on arable land, the optimal ratio of plowed land, hayfields and pastures will eliminate the destructive processes occurring in agricultural landscapes, reduce erosion and increase soil fertility and crop yields.

Today in Ukraine and the world promising competitive adaptive technologies for growing legumes based on the characteristics of growth, development and yield formation with a comprehensive study and differentiated combination in the technological process of basic elements: varieties, fertilizers, tillage, crop protection from weeds , pests and diseases, as well as studies their biologized models, involving the introduction of low doses of mineral fertilizers in combination with by-products (noncommercial) products of predecessors. These technologies make it possible to obtain a yield of peas - 3.5-4.0, white lupine - 3.2-3.5, yellow lupine 2.0-2.2, narrow-leaved lupine $-3.0-3.2$, beans $-2.5-2.8 \mathrm{t} / \mathrm{ha}$. However, the weak point of such technologies is the binding to specific types of soils, unidirectional application of classical mineral fertilizers, focus on the 
standard format of microfertilizers, lack of tactics of concomitant control over changes in soil fertility, conflicting data on the effectiveness of such technologies for tillage and exposure to stressors. As a result, the efficiency of the real realization of the yield potential of the outlined range of legumes by $30-55 \%$, and for a number of promising valuable legumes chickpeas, lentils - up to $60-68 \%$. Such aspects confirm the relevance, innovation and production significance of the objectives and its national research and production relevance for the agro-industrial complex of Ukraine and world agricultural practice.

\section{Conditions, objective and methods of research}

Field experiments were conducted during 2016-2020 on the basis of the Research Farm «Agronomiche» of Vinnytsia National Agrarian University in the village of Agronomichne of Vinnytsia district of Vinnytsia region.

Based on the data of the Vinnytsia Regional Center for Hydrometeorology, hydrothermal conditions were assessed. The climate of the Forest-Steppe zone is temperate-continental. The average annual air temperature is at $13.1{ }^{\circ} \mathrm{C}$. The absolute minimum and maximum temperature are $36.0{ }^{\circ} \mathrm{C}$, respectively. The number of days and the height of snow cover, respectively, are in the range of 70-110 days and 20-60 cm. The amount of precipitation varies from 125 to $369 \mathrm{~mm}$ per year and falls mainly in the summer-autumn period.The soil cover is represented by gray forest soils. Depth of humuseluvial horizon up to $30 \mathrm{~cm}$, gray. According to the soil survey of the Vinnytsia Regional State Design and Technology Center for Soil Protection and Product Quality «Regional State Fertility» it is noted that the soils of the study area are characterized by low humus content $-1.97 \%$. Agrochemical characteristics of gray forest soils are given in table 1 .

Growing technology is generally accepted for the Forest-Steppe zone of Ukraine, except for the envisaged technological methods of cultivation. The research included the study of the action and interaction of 3 factors: A - grade; B - pre-sowing treatment of seeds with a bacterial preparation; $\mathrm{C}-$ is the concentration of the retardant.

On the day of sowing legume seeds were treated with the bacterial drug Rhizohumin (600 g per hectare of seeds). During the growing season of sown peas, soybeans, white lupins and narrow-leaved lupins (budding phase) on the variants of experiments according to the scheme used a 
Table 1

Agrochemical characteristics of the soil of the experimental field (according to «Regional State Fertility»)

\begin{tabular}{|c|c|c|c|c|c|}
\hline $\begin{array}{c}\text { Depth of } \\
\text { sampling, } \\
\text { cm }\end{array}$ & $\begin{array}{c}\text { Humus } \\
\text { content,\% }\end{array}$ & pH salt & $\begin{array}{c}\text { Hydrolytic } \\
\text { acidity, } \\
\text { mg.-eq. per } \\
\mathbf{1 0 0} \text { g of soil }\end{array}$ & $\begin{array}{c}\text { The amount } \\
\text { of absorbed } \\
\text { bases, } \\
\text { mg.-eq. per } \\
\mathbf{1 0 0} \text { g of soil }\end{array}$ & $\begin{array}{c}\text { The } \\
\text { degree of } \\
\text { saturation } \\
\text { of the } \\
\text { bases, \% }\end{array}$ \\
\hline $0-20$ & 1,97 & 5,1 & 3,44 & 14,38 & 86 \\
\hline $30-40$ & 1,39 & 4,9 & 3,48 & 14,06 & 88 \\
\hline $65-75$ & 0,66 & 4,6 & 3,45 & 13,10 & 86 \\
\hline $95-105$ & not specified & 4,4 & 3,32 & 13,63 & 85 \\
\hline $125-135$ & not specified & 4,4 & 3,37 & 13,49 & 88 \\
\hline
\end{tabular}

retardant - chlormequat chloride, v.r. (750 g/l) f. BASF CE, Germany, in different concentrations (working solution rate 200 1/ha), which belongs to the group of Quaternary ammonium compounds.

During the research, the scheme of the experiment was developed according to the methodology of the research case, as well as observations, accounting, calculations were performed. Field, statistical and laboratory research methods were used in the experimental work. The indicators obtained in the experiments from legumes were processed by the method of analysis of variance.

During the scientific experiment, the following approaches were used: a) system approach, which will allow to consider ecologically safe agrotechnologies as a multicomponent system based on the principles of energy saving with the achievement of economic effect; b) analytical approach, which involves the use of correlation regression approaches in the assessment of models of transition to bioorganic tillage technologies in terms of classical, surface and minimized schemes; c) activity approach that will allow to carry out production inspection of the developed models of agrotechnologies; d) information approach, which provides for information and consulting practice with the involvement of a network of agricultural formations of various forms of ownership in order to implement reliable source data and systematize the information obtained. This integrated approach will separate and implement unified models of agrobiological and ecological-economic assessment of efficient production of high-protein 
crops in terms of resource conservation, restoration of soil fertility and stable microbiological condition in climate change. Within the framework of the proposed research model, it is planned to use both traditional and new tested methods. The new ones include:

- determination of the factor influence of bioorganic fertilizer variants on the growth and physiological processes of plants based on the analysis of phytosynthetic activity and induction indicators of chlorophyll;

- conducting modular and vitality studies using regression-correlation models of the formation of legume yields for different variants of biological systems for their cultivation;

- application of non-traditional approaches to phytoindication of soil fertility conditions and appropriate fertilizer levels in order to find the optimal ratio between the preservation of optimized soil processes and the appropriate economically feasible levels of their yield;

- assessment of stress-regulating levels of developed technologies by studying the peculiarities of plasticity and yield stability of basic legumes at different levels of bioorganic fertilizer systems based on criteria such as asymbatics of plant morphotypes, idiotypic structure of agrophytocenosis, modular and morphological aspects of productivity formation;

- analysis of growth curves, application of mathematical modeling and forecasting methods based on computer modeling system;

- systematic concomitant approach in the study of soil fertility parameters for different technologies used for growing legumes and the creation of soilplant models in search of the optimal model for growing legumes according to the principles of ecological and economic feasibility;

- determination of parameters of organic matter content, absorption capacity, content of mobile forms of basic nutrients, biological potential of soil, optimized parameters of physical properties of soil, etc.

Objectives of the study:

1) to develop a competitive bioorganic varietal technology for growing legumes with the achievement of economic effect from the introduction of energy-intensive resources;

2) to form effective regulations for the use of different types of biofertilizers for the growing season according to their different types in the system of agrotechnologies for growing legumes; 
3) to develop optimized and adapted systems of application of bioorganic agrochemicals in the system of soil use on the basis of mobilization agrochemical approaches (taking into account the soil fertility potential and the system of microbiological and chemical transformations in the soilplant system);

4) to develop and implement stage models of transition to bioorganic technologies of tillage in the context of classical, surface and minimized schemes.

As a result of research, it is expected to develop effective new technological regulations for growing legumes on the basis of partial and complete biologization, taking into account soil fertility conditions and climatic resource potential of the region. It is planned to develop models of such technologies on the basis of correlation-regression estimates and simulation factor modeling taking into account modern technological trends of tillage: classical system, differentiated and surface systems. The effective implementation of the results of the developed technologies and their scientific zonal testing is expected.

It is planned to introduce unified models of agrobiological and ecological-economic assessment of efficient production of high-protein crops in view of resource conservation, restoration of soil fertility and stable microbiological condition in the conditions of climate change. Theoretical and practical data of the monograph will be useful in the formation of the Concept of the State target program for the development of the agricultural sector for the period up to 2030, amendments to the Law of Ukraine «On production and circulation of organic agricultural products and raw materials» from 03.09.2013 № 425-VII, Concepts of the state program of development of organic production in Ukraine, effective formation of «Strategy of economic development of Ukraine 2030», formation of trend and target development of agro-industrial production at the national level for the period till 2050 .

\section{Grain yield of legumes depending on technological methods of cultivation}

Yield is a complex complex feature, which is manifested on the basis of the functional activity of various plant organs that make up their morphological and physiological structure. Each organ (root, stem, leaf, 
bean) is formed at a certain stage of ontogenesis. Their activity is limited to different time periods and are regulated by the genetic apparatus of organisms in a complex interaction with environmental conditions.

The stem of dicotyledons, in contrast to annual cereals, does not form a terminal inflorescence and is actually unlimited in growth. The need for stable access to basic mineral elements during evolution has led to the formation of additional adaptations characteristic of individual species or entire families of a particular class of plants. First of all, it is the release into the soil of a complex of organic acids and various forms of symbiotic relationships with fungi and bacteria. In modern crop production, only one of the following types of symbiosis is effectively used: between legumes and nitrogen-fixing bacteria. Management of this process involves the use of specialized breeding strains of microorganisms, a set of measures to optimize the conditions of symbiosis.

It is established that in general the Right-Bank Forest-Steppe of Ukraine in terms of soil-climatic and hydrothermal conditions is favorable for growing legumes and forming their high grain productivity. The results of research indicate a significant impact of the studied technological methods of cultivation on the level of yield of legumes (Table 2).

Over the years of experimental research, the maximum indicators of grain and fodder productivity in the varieties of the proposed legumes have been determined. Therefore, in sowing peas the most productive variety was Prystan (yield - $2.62 \mathrm{t} / \mathrm{ha}$, crude protein yield - $1.09 \mathrm{t} / \mathrm{ha}$ ), white lupine Chabanskyi (yield - $3.47 \mathrm{t} / \mathrm{ha}$, crude protein yield - $1.33 \mathrm{t} / \mathrm{ha}$ ), narrowleaved lupine - Peremojets (yield $-2.67 \mathrm{t} / \mathrm{ha}$, crude protein yield $-1.10 \mathrm{t} / \mathrm{ha}$ ), and soybeans - Azimuth (yield - $2.68 \mathrm{t} / \mathrm{ha}$, yield) crude protein $-1.35 \mathrm{t} / \mathrm{ha}$ ). The largest increases in grain and fodder productivity were obtained by seed treatment with the bacterial preparation Rhizohumin and spraying of crops with chlormequat chloride retardant in the budding phase.

\section{Content and yield of crude grain protein}

\section{of legumes depending on technological methods of cultivation}

Due to the high protein content in the plant and its adaptation to different soil and climatic conditions, lupine is an indispensable forage crop. The criterion for assessing the activity of the functioning of symbiotic systems can be not only the seed productivity of legumes, but also the content of crude protein in the grain. 


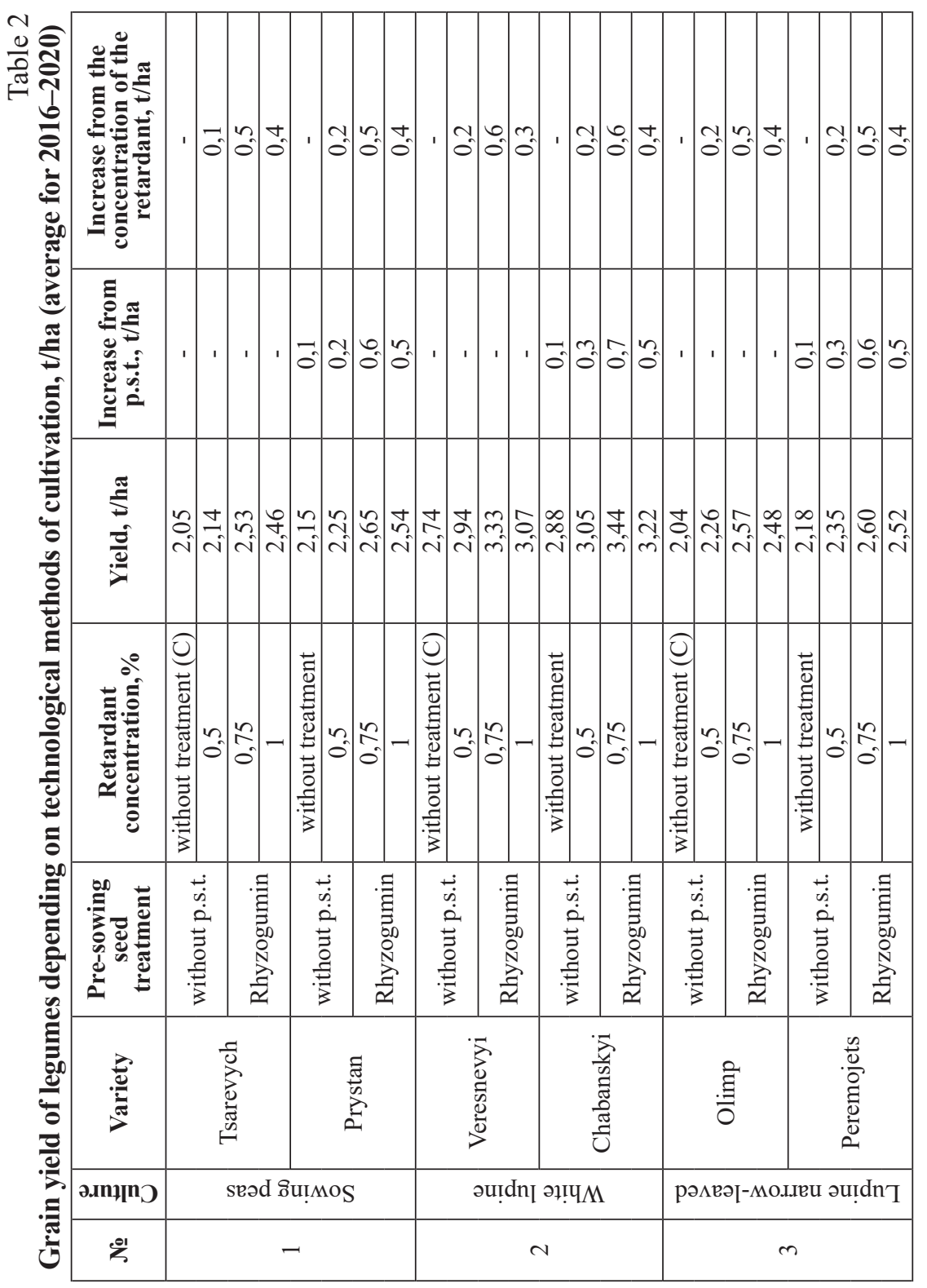


Victor Mazur, Ihor Didur

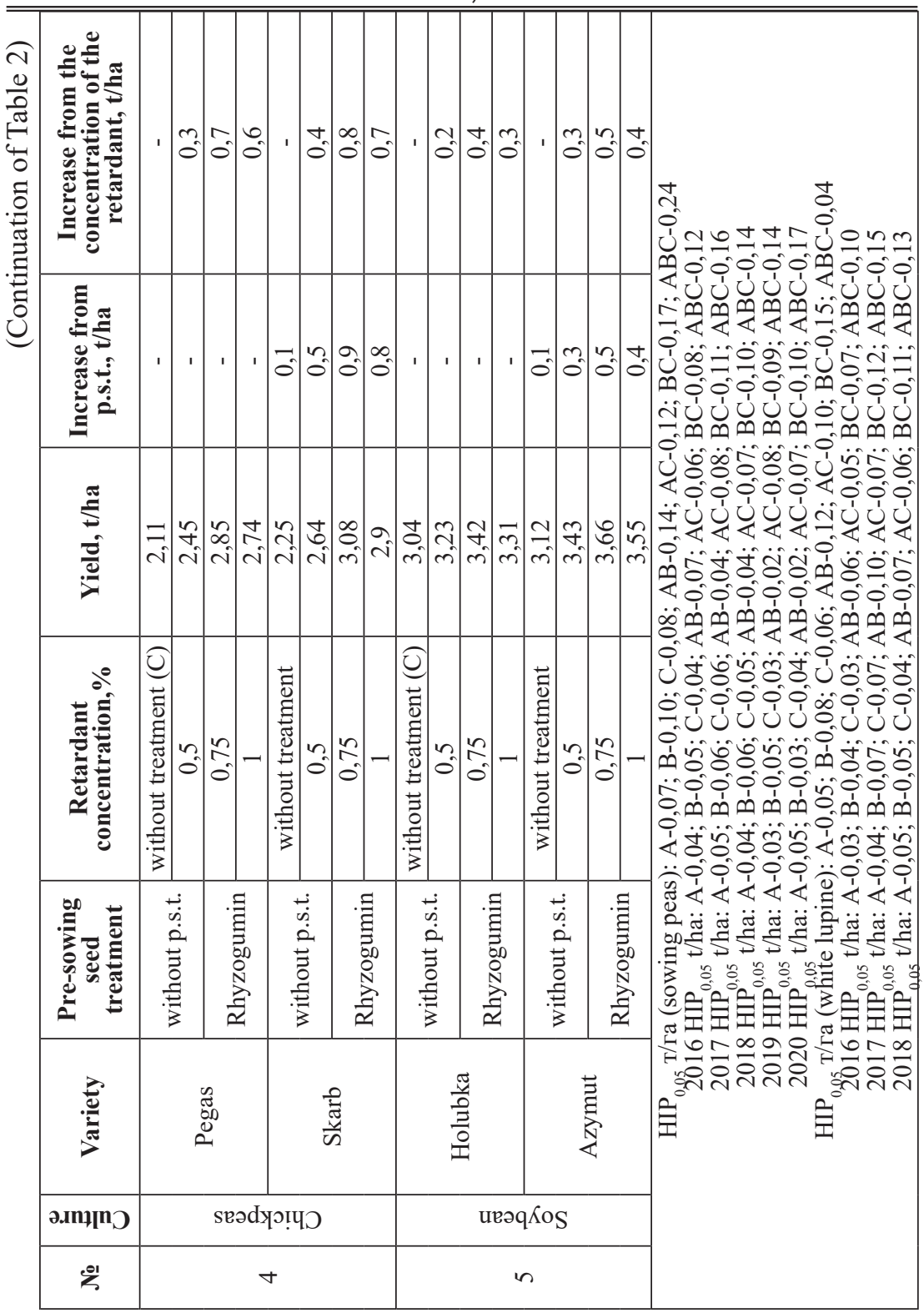




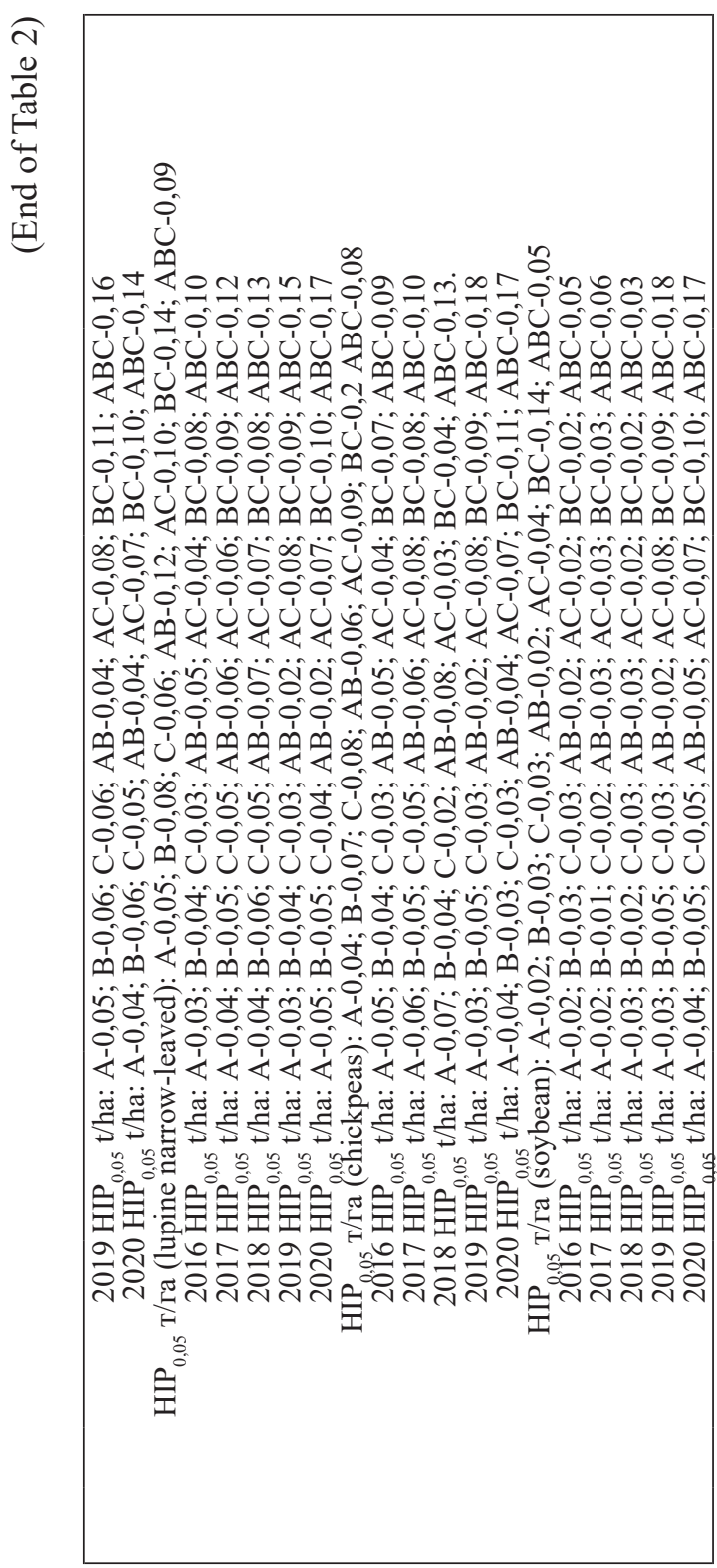


The study of the peculiarities of the formation of crude protein content in legumes and its yield per unit area depending on the elements of cultivation technology is important theoretical and practical value to substantiate the possibilities and feasibility of growing this legume in the Right-Bank ForestSteppe. As a result of the conducted researches it is established that with increase in grain yield the yield of crude protein also increased (Table 3).

Due to the increase in yield, the highest yield of crude protein $(0.93-$ $1.19 \mathrm{t} / \mathrm{ha}$ ) was in white lupine plants. Thus, in pea sowing the yield of crude protein was the highest in the variety Prystan (0.59 t/ha), white lupine Chabanskyi (1.19 t/ha), narrow-leaved lupine - Peremozhets (0.87 t/ha), chickpeas - Skarb (0.82 t/ha) and in soybeans - Azimuth (0.98 t/ha). The largest increases in crude protein yield per unit area were obtained by seed treatment with the bacterial preparation Rhizohumin and spraying of crops with chlormequat chloride retardant in the budding phase.

\section{Practical value}

The introduction of the results of the monograph will increase the attractiveness of the market for high-protein production due to cheaper production costs by recommending domestic varieties of legumes by at least $20-25 \%$ while reducing the cost of production in the pre-calculated range by $20-33 \%$. The proposed system of using domestic varietal resources will stimulate revenues to local budgets by further expanding the production of recommended biological products by regional enterprises by at least $8-10 \%$. This, in turn, will stimulate the reduction of exports of raw materials and create conditions for the organization of in-depth processing, which will contribute to: meeting the needs of intensive animal husbandry with high-protein feed; providing the population with food, creating additional jobs; increase in tax revenues; ensuring food and environmental security of Ukraine. Scientific development will contribute to the effective European integration of Ukraine and the overall improvement of agricultural products that meet international standards, will increase the effectiveness of Ukraine's state policy in organic and organic farming, contribute to the stabilizing slowdown in natural soil fertility, increase humus and chemical state for subsequent generations. To do this, we focus on optimizing the structure of sown areas of leading crops, development and implementation of scienceintensive, innovative technologies for their cultivation, which will be based 


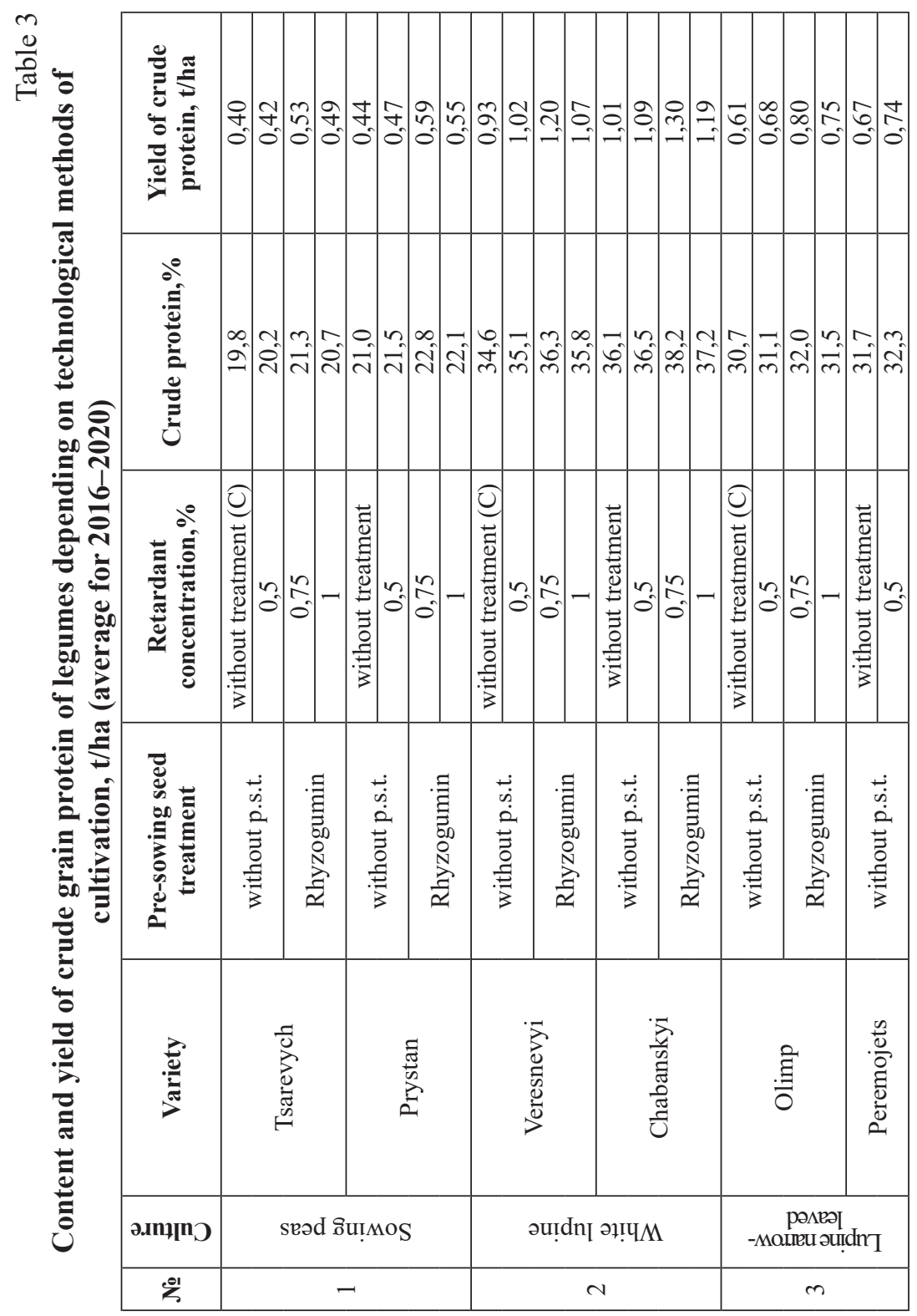




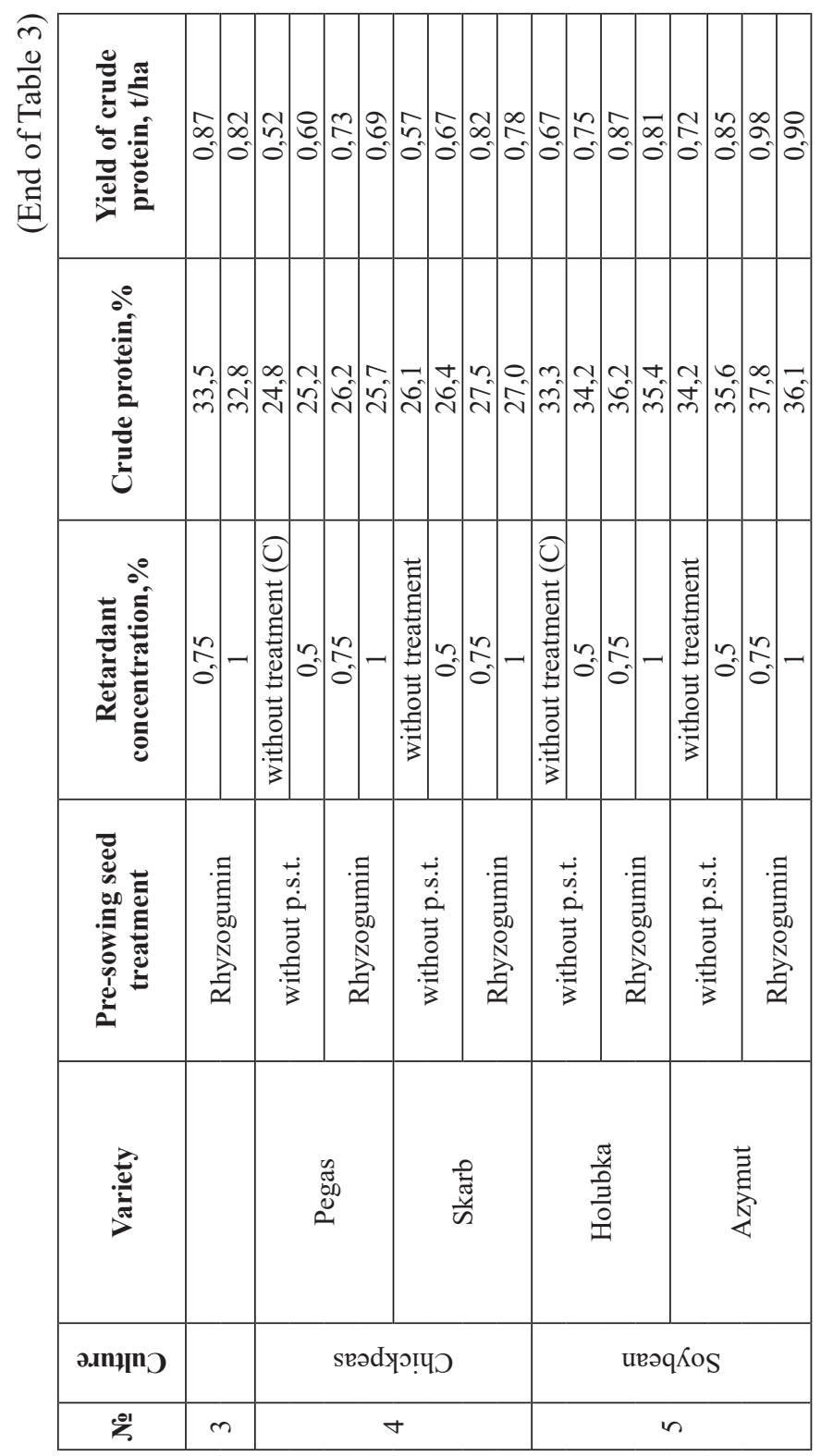


on the effective use of life factors (light, heat, moisture, nutrients), which will promote maximum synthesis of organic matter and protein.

\section{Conclusions}

Based on the research, it was found that the indicators of grain productivity are directly influenced by soil and climatic conditions of the years of the study and the factors that were put to the study. The best conditions for the maximum realization of the potential of legumes are created by treating the seeds with the bacterial preparation Rhizohumin and spraying the crops with a retardant of chlormequat chloride in the budding phase. Our improved model of bioorganic varietal technology for growing legumes using the proposed bioorganic and technological measures will increase the production of quality grain of the studied crops, increase the total harvest of crude protein and increase the level of biological nitrogen fixation in the Forest-Steppe Right Bank.

\section{References:}

1. Babych A.O. (1993). Problemy bilka i vyroshchuvannia zernobobovykh na korm. Problems of protein and growth of legumes for feed. 3-ye vyd., pererobl. i dopov. Kyiv, 429 p.

2. Bakhmat O.M. (2012). Modeliuvannia adaptyvnoi tekhnolohii vyroshchuvannia soi. Modeling adaptive technology of soybean cultivation Monohrafiia. Kamianets-Podilskyi: Vydavets: PP Zvolenko D. H.

3. Bandura V., Mazur V., Yaroshenko L., Rubanenko O. (2019). Research on sunflower seeds drying process in a monolayer tray vibration dryer based on infrared radiation. INMATEN - Agricultural Engineering, vol. 57, no. 1, pp. 233-242.

4. Begey S.V., Shuvar I.A. (2007). Ecological Agriculture: Textbook. Lviv: Novyi Svit-2000, 429 p.

5. Bransby D.I. Compatibility of switchgrass as an energy crop in farming systems of the southeastern USA. D.I. Bransby, R. Rodriguez-Kabana.

6. Bulgakov V., Adamchuk V., Kaletnik G., Arak M., Olt J. (2014). Mathematical model of vibration digging up of root crops from soil. Agronomy Research, no. $12(1)$, pp. $41-58$.

7. Cholovskyi Yu.M. (2010). Osoblyvosti vodospozhyvannia posivamy liupynu vuzkolystoho zalezhno vid zastosuvannia mineralnykh dobryv. Kormy $i$ kormovyrobnytstvo - Forage and feed production, vol. 66, pp. 146-147.

8. Cultural Pasture: Patent No 40618 / V. L. Puyu, M. I. Bakhmat, S. A. Tsvigun; Podillya State Agrarian Engineering University, UA. Application dated 01.07.2008; published 27.04.2009. Industrial Property. Kyiv, 2009. Bulletin No 8.

9. Didur I., Bakhmat M., Chynchyk O., Pantsyreva H., Telekalo N., Tkachuk O. (2020). Substantiation of agroecological factors on soybean agrophytocenoses by 
analysis of variance of the Right-Bank ForestSteppe in Ukraine. Ukrainian Journal of Ecology, no. 10(5). pp. 54-61.

10.Didur I., Pantsyreva H., Telekalo N. (2020). Agroecological rationale of technological methods of growing legumes. The scientific heritage, 52, pp. 3-14.

11. Dospekhov B.A. (1985). Metodyka polevoho opyta (s osnovamy statystycheskoi obrabotky rezultatov yssledovanyi). Yzd. 5-e dop. y pererab. Moscow: Ahropromyzdat, $351 \mathrm{p}$.

12. Environmental Issues of Agriculture (2010) / I.D. Prymak, Y.P. Manko, N.M. Ridey et al.; Ed. I.D. Primak. Kyiv: Center of Educational Literature, 456 p.

13.Environmental Problems of Agriculture: Tutorial: V.P. Gudz, M.F. Rybak, S.P. Tanchyket al.; Ed. V. Gudz. Zhytomyr National Agroecological University Press, 2010. 708 p.

14.Ermakov, A., Arasymovych, V., Yarosh, N. et al. (1987). Methods Studies biochemically plants. L.: Agropromizdat, P. 430.

15.G.A. Esbroeck, M.A. Hussey, M.A. Sanderson. Crop Sci, 1997. No. 37, pp. 864-870. URL: http://journals.nubip.edu.ua/index.php/Dopovidi/article/ view/13901/12328

16. Ishchenko, V. Belyakov, A. (2009). Efficiency of micronutrients, growth regulator and ryzohuminu in increasing productivity varieties of peas without leaves type. Steppe Bulletin, 6: 37-41.

17. Kaletnik G.M., Zabolotnyi, G.M. Kozlovskyi S.V (2011). "Innovative models of strategic management economic potential within contemporary economic systems". Actual Problems of Economics, vol. 4(118), pp. 11.

18. Kaletnik, G., \& Lutkovska, S. (2020). Innovative Environmental Strategy for Sustainable Development. European Journal of Sustainable Development, 9(2), 89. https://doi.org/10.14207/ejsd.2020.v9n2p89

19. Kolesnik, S. (2012). Bacterial fertilizer to optimize nitrogen and phosphorus nutrition soybeans, chickpeas, peas, lentils and commit. Feed and fodder, 73: 145-151.

20. Ma Z. (2001). Impact of row spacing, nitrogen rate, and time on carbon partitioning of switchgrass Z. Ma, C. W. Wood, D. I. Bransby. Biomass Bioenergy, no. 20, pp. 413-419.

21. Malchevskaya, E., Mylenkaya, G. (1981). The comments and Animal Husbandry quality forage analysis. Minsk . Harvest, p. 143.

22. Mazur O.V., Kolisnyk O.M., Telekalo N.V. (2017). Genotypic differences in varieties of common beans by manufacturability. Collection of scientific works of VNAU «Agriculture and forestry», 7. (T. 2), pp. 33-39.

23. Mazur V., Didur I., Myalkovsky R., Pantsyreva H., Telekalo N., Tkach O. (2020). The productivity of intensive pea varieties depending on the seeds treatment and foliar fertilizing under conditions of right-bank forest-steppe Ukraine. Ukrainian Journal of Ecology, no. 10(1), pp. 101-105.

24. Mazur V.A., Didur I.M., Pantsyreva H.V., Telekalo N.V. (2018). Energyeconomic efficiency of growth of grain-crop cultures in conditions of Right-Bank Forest-Steppe of Ukraine. Ukrainian Journal of Ecology, no. 8(4), pp. 26-33.

25. Mazur V.A., Mazur K.V., Pantsyreva H.V. (2019). Influence of the technological aspects growing on quality composition of seed white lupine (Lupinus 
albus L.) in the Forest Steppe of Ukraine. Ukrainian Journal of Ecology, vol. 9, pp. 50-55. URL: https://www.ujecology.com/archive.html

26. Mazur V.A., Mazur K.V., Pantsyreva H.V., Alekseev O.O. (2018). Ecological and economic evaluation of varietal resources Lupinus albus L. in Ukraine Ukrainian Journal of Ecology, vol. 8, pp. 148-153.

27. Mazur, V. A., Prokopchuk, V. M., \& Pantsyreva, G. V. (2018). Primary introduction assessment of decorative species of the lupinus generation in Podillya. Scientific Bulletin of UNFU, 28(7), 40-43. https://doi.org/10.15421/40280708

28. Mazur V.A., Pantsyreva H.V. (2020). «Rid Lupinus L. v Ukraini: henofond, introduktsiia, napriamy doslidzhen ta perspektyvy vykorystannia». VNAU, p. 235.

29. Mazur V.A., Pantsyreva H.V., Didur I.M., Prokopchuk V.M. (2018). Liupyn bilyi. Henetychnyi potentsial ta yoho realizatsiia u silskohospodarske vyrobnytstvo. VNAU, p. 231.

30. Mazur V.A., Pantsyreva H.V., Mazur K.V., Didur I.M. (2019). Influence of the assimilation apparatus and productivity of white lupine plants. Agronomy Research, 17(X), 206-209. URL: https://doi.org/10.15159/AR.19.024

31. Mazur V.A., Pantsyreva H.V., Mazur K.V., Didur I.M. (2019). Influence of the assimilation apparatus and productivity of white lupine plants. Agronomy Research, 17(X), 206-209. URL: https://doi.org/10.15159/AR.19.024

32. Mazur V.A., Pantsyreva H.V., Mazur K.V., Myalkovsky R.O., Alekseev O.O. (2020). Agroecological prospects of using corn hybrids for biogas production. Agronomy Research, 18(1), 177-182.

33. Mazur, V.A., \& Pantsyreva, H.V. (2017). Vplyv tekhnolohichnykh pryiomiv vyroshchuvannia na urozhainist i yakist zerna liupynu biloho $\mathrm{v}$ umovakh Pravoberezhnoho Lisostepu. Silske hospodarstvo i lisivnytstvo, 7, 27-36.

34. Mazur, V.A., Myalkovsky, R.O., Mazur,K.V., Pantsyreva,H.V.,Alekseev, O.O. (2019). Influence of the Photosynthetic Productivity and Seed Productivity of White Lupine Plants. Ukrainian Journal of Ecology, 9(4), 665-670.

35. Mazur, V.A., Myalkovsky, R.O., Mazur, K.V., Pantsyreva, H.V., Alekseev, O.O. (2019). Influence of the Photosynthetic Productivity and Seed Productivity of White Lupine Plants. Ukrainian Journal of Ecology, 9(4), 665-670.

36. Mazur, V.A., Branitskyi, Y.Y., Pantsyreva, H.V. (2020). Bioenergy and economic efficiency technological methods growing of switchgrass. Ukrainian Journal of Ecology, 10(2), 8-15.

37. Mazur, V.A., Didur, I.M., Pantsyreva, H.V., \& Telekalo, N.V. (2018). Energy-economic efficiency of grain-crop cultures in the conditions of the rightbank Forest-Steppe of Ukraine. Ukrainian J Ecol, 8(4), 26-33.

38. Mazur, V.A., Mazur, K.V., Pantsyreva, H.V., Alekseev, O.O. (2018). Ecological and economic evaluation of varietal resources Lupinus albus L. in Ukraine. Ukrainian Journal of Ecology, 8(4), 148-153.

39. Mazur, V.A., Pantsyreva, H.V., Mazur, K.V. \& Didur, I.M. (2019). Influence of the assimilation apparatus and productivity of white lupine plants. Agronomy research, 17(1), 206-219. 
40. Melnychuk, T., Patyka, V. (2011). Microbial preparations bioorganic farming system. Collected articles «Third All-Ukrainian Congress of Ecologists with international participation». Vinnytsya, Tom 2, pp. 423-426.

41. Metodologiya i praktyka vykorystannya mikrobnyx preparativ u texnologiyax vyroshhuvannya silskogospodarskyx kultur [Methodology and practice of microbial drugs use in crop growing technologies] / V.V. Volkogon, A. S. Zaryshnyak, I.V. Grynyk ta in. (2011). Kyyiv: Agrarna nauka, 153.

42. Monarkh Veronika Valentynivna, Pantsyreva Hanna Vitaliivna (2019). Stages of the Environmental Risk Assessment. Ukrainian Journal of Ecology, 9(4), 484-492. DOI: $10.15421 / 2019779$

43. Muir J.P. (2001). Biomass production of Alamo switchgrass in response to nitrogen, phosphorus, and row spacing. J.P. Muir, M.A. Sanderson, W.R. Ocumpaugh at all. Agron J., no. 93, pp. 896-901.

44. Naum Raichesberg (2000). Adolphe Quetelet, His Life and Research Activities. Moscow: Elibron Classics, 98 p.

45. Ovcharuk V.I., Mulyarchuk O.I., Myalkovsky R.O., Bezvikonnyi P.V., Kravchenko V.S., Klymoych N.M. (2019). Parameters of beet plants. Bulletin of the Uman National University of Horticulture, no. 1, pp. 70-75.

46. Palamarchuk V., Honcharuk I., Honcharuk T., Telekalo N. (2018). Effect of the elements of corn cultivation the technology on bioethanol production under conditions of the rightbank forest-steppe of Ukraine. Ukrainian Journal of Ecology, vol. 8(3), pp. 47-53.

47.Palamarchuk, V. \& Telekalo, N. (2018). The effect of seed size and seeding depth on the components of maize yield structure. Bulgarian Journal of Agricultural Science, 24(5), 785-792.

48. Palamarchuk, V., Telekalo, N. (2018). The effect of seed size and seeding depth on the components of maize yield structure. Bulgarian Journal of Agricultural Science, 24(5), 785-792.

49.Pancy reva G.V. (2016). Doslidzhennya sortovy`x resursiv lyupy`nu bilogo (Lupinus albus L.) v Ukrayini. Vinnycya, 4, 88-93.

50. Pantsyreva H.V. (2018). Research on varietal resources of herbaceous species of Paeonia L. in Ukraine. Scientific Bulletin of the NLTU of Ukraine, 28(8), 74-78. https://doi.org/10.15421/40280815

51.Pantsyreva, H.V. (2016). Doslidzhennia sortovykh resursiv liupynu biloho (Lupinus albus L.) v Ukraini. Silske hospodarstvo i lisivnytstvo, 4, 88-93.

52. Pantsyreva, H.V. (2019). Morphological and ecological-biological evaluation of the decorative species of the genus Lupinus L. Ukrainian Journal of Ecology, 9(3), 74-77.

53. Pantsyreva, H.V. (2019). Technological aspects of biogas production from organic raw materials. Bulletin of KhNTUSG them, pp. Vasilenko. Kharkiv, pp. 276-290.

54.Puyu V.L. (2014). Modern Design of Cultivated Pastures in the Western Forest Steppe. Seminar Program of Uman NUS «Varietal Technologies as a Factor in the Implementation of Agrocenoses Biopotentials in the Programming System of Field and Forage Crops Yield». Uman, 15-16 May 2014.

55.Puyu V.L., Bakhmat M.I., Rykhlivskyi I.P., Shcherbatiuk N.V. (2019). Optimization of Conveyor Production of Green Fodder. World Science, no. 7(47), vol. 1. doi: 10.31435/rsglobal_ws/31072019/6587 
56. Rai R.K., Tripathi N., Gautam D., \& Singh P. (2017). Exogenous application of ethrel and gibberellic acid stimulates physiological growth of late planted sugarcane with short growth period in subtropical India. Journal of Plant Growth Regulation, 36(2), 472-486.

57. S.E. Sladden. (1993). Biomass Conf. of the Americas. Burlington, pp. 229-234.

58. Shatilov I.S., Chudnovskyi A.F. (1980). Agrophysical, Agrometeorological and Agrotehnical Crop Programming Fundamentals: ACS of TP Principles in Land Cultivation. Leningrad: Gidrometeoizdat, 320 p.

59. Telekalo N., Mordvaniuk M., Shafar H., Matsera O. (2019). Agroecological methods of improving the productivity of niche leguminous crops. Ukrainian Journal of Ecology, no. 9(1), pp. 169-175.

60. Telekalo N.V. (2016). Economic evaluation of the efficiency of pea growing technology. Collection of scientific works of VNAU «Agriculture and forestry», 4, pp. 63-71.

61. Tymchuk, O. Shkvirko, H. Sakalova, M. Malovanyy, T. Dabizhuk, O. Shevchuk, O. Matviichuk, T. Vasylinych (2020). Wastewater a Source of Nutrients for Crops Growth and Development. Journal of Ecological Engineering, vol. 21, issue 5, pp. 88-96.

62.V.G. Kuryata, S.V. Polyvanyi, O.A. Shevchuk, O. Tkachuk (2019). Morphogenesis and the effectiveness of the production process of oil poppy under the complex action of retardant chlormequat chloride and growth stimulant treptolem. Ukrainian Journal of Ecology, 9(1), 127-134.

63. Vdovenko S.A., Prokopchuk V.M., Palamarchuk I.I., Pantsyreva H.V. (2018). Effectiveness of the application of soil milling in the growing of the squash (Cucurbita pepo var. giraumontia) in the right-benk forest stepp of Ukraine. Ukrainian Journal of Ecology, 8(4), 1-8.

64. Vdovenko S.A., Prokopnuk V.M., Palamarchuk I.I., Pantsyreva H.V. (2018). Effectiveness of the application of soil milling in the growing of the squash (Cucurbita pepo var. giraumontia) in the right-benk forest stepp of Ukraine. Ukrainian Journal of Ecology, 8(4), 1-5.

65. Vdovenko, S.A., Pantsyreva, G.V., Palamarchuk, I.I., \& Lytvyniuk, H.V. (2018). Symbiotic potential of snap beans (Phaseolus vulgaris L.) depending on biological products in agrocoenosis of the right-bank forest-steppe of Ukraine. Ukrainian J Ecol, 8(3), 270-274.

66. Vdovenko, S.A., Prokopchuk, V.M., Palamarchuk, I.I., \& Pantsyreva, H.V. (2018). Effectiveness of the application of soil milling in the growing of the squash (Cucurbita pepo var. giraumontia) in the right-benk forest stepp of Ukraine. Ukrainian J Ecol, 8(4), 1-5.

67. Vitalii Palamarchuk, Inna Honcharuk, Tetiana Honcharuk, Natalia Telekalo (2018). Effect of the elements of corn cultivation technology on bioethanol production under conditions of the right- bank forest-steppe of Ukraine. Ukrainian Journal of Ecology, no. 8(3), pp. 47-53.

68. Vitalii Palamarchuk, Inna Honcharuk, Tetiana Honcharuk, Natalia Telekalo (2018). Effect of the elements of corn cultivation technology on bioethanol production under conditions of the right- bank forest-steppe of Ukraine. Ukrainian Journal of Ecology, no. 8(3), 47-53. 
69. Wolters D., Beste A. (2000). Biomasse - umweltfreundlicher Energieträger? Ökologie und Landbau. 116, 4, s. 12-14.

70.Xing, X., Jiang, H., Zhou, Q., Xing, H., Jiang, H., \& Wang, S. (2016). Improved drought tolerance by early IAA - and ABA-dependent $\mathrm{H} 2 \mathrm{O} 2$ accumulation induced by $\alpha$-naphthaleneacetic acid in soybean plants. Plant Growth Regulation, 80(3), 303-314.

71. Yanovych, V., Honcharuk, T., Honcharuk, I. \& Kovalova, K. (2017). Design of the system to control a vibratory machine for mixing loose materials. EasternEuropean Journal of Enterprise Technologies, 6(3-90), 4-13.

72. Yanovych, V., Honcharuk, T., Honcharuk, I. \& Kovalova, K. (2018). Engineering management of vibrating machines for targeted mechanical activation of premix components. INMATEH - Agricultural Engineering, 54(1), 25-32.

73. Yhurber J.A. (1958). Inhibitory effect of gibberellins on nodulation in dwarf beans, Phaseolus vulgaris. Nature, vol. 181, pp. 1082-1083.

74. Yowling W.A., Buirchell B.J., Tarta M.E. Lupin. Lupinus L. (1998). Promoting the conservation and use of underutilized and neglected crops 23. Institute of Plant lyenetis and crop Plant Research, yatersleben. International Plant lyenetic Resources Institute. Rome, pp. 112-114.

75.Zhao, H., Cao, H., Ming-Zhen, P., Sun, Y., \& Liu, T. (2017). The role of plant growth regulators in a plant aphid parasitoid tritrophic system. Journal of Plant Growth Regulation, 36(4), 868-876.

76.O.A. Shevchuk, O.O. Tkachuk, V.G. Kuryata, O.O. Khodanitska, S.V. Polyvanyi (2019). Features of leaf photosynthetic apparatus of sugar beet under retardants treatment. Ukrainian Journal of Ecology, 9(1), 115-120.

77.O.O. Khodanitska, V.G. Kuryata, O.A. Shevchuk, O.O. Tkachuk, I.V. Poprotska (2019). Effect of treptolem on morphogenesis and productivity of lin seed plants. Ukrainian Journal of Ecology, 9(2), 9-126.

78. Cowling W.A. (1994). Plant breeding for stable agriculture: Presidential Address. Western Australia, 183-184. 